\title{
Environmental determinants for natural regeneration of gallery forest at the Cerrado/Amazonia boundaries in Brazil
}

\author{
Beatriz Schwantes MARIMON¹, Jeanine Maria FELFILI², Edson de Souza LIMA³, Wânia M. Gonçalves \\ DUARTE ${ }^{4}$, Ben Hur MARIMON-JÚNIOR ${ }^{5}$
}

\begin{abstract}
Natural regeneration and structure and their relationship to environmental variables were studied in three sections of a gallery forest, in Eastern Mato Grosso, Brazil (14\% ${ }^{\circ} 3^{\prime} \mathrm{S}$ and $\left.52^{\circ} 21^{\prime} \mathrm{W}\right)$. The assumption was that natural regeneration is constrained by environmental determinants at all stages of development of the tree community. The objective was to analyse the forest structure and to verify the relationship between species distribution and abundance at different stages of regeneration and environmental variables. In each section, 47 contiguous $(10 \times 10 \mathrm{~m})$ permanent plots were established to sample trees $(\mathrm{gbh} \geq 15 \mathrm{~cm})$, following a systematic design. Seedlings ( 0.01 to $1 \mathrm{~m}$ height), saplings $(1.01$ to $2 \mathrm{~m}$ ) and poles (from $2.01 \mathrm{~m}$ height to gbh $<15 \mathrm{~cm}$ ) were sampled in sub-plots of $1 \times 1 \mathrm{~m}, 2 \times 2 \mathrm{~m}$ and $5 \times 5 \mathrm{~m}$, respectively. In each plot, soil properties, gaps projection, bamboos, rocky cover, declivity and depth of ground watertable were determined. The relationships between the environmental variables with trees and seedling communities were assessed by canonical correspondence analysis. In spite of the sections being near to each other, they presented large differences in floristics, structure and site conditions. The forest soil presented a low cation exchange capacity and a high level of Al saturation. The occurrence of bamboos and gaps and the depth of ground watertable limited the occurrence of poles and trees. The high degree of structural heterogeneity for each regeneration category was related primarily to a humidity gradient; but soil fertility $(\mathrm{Ca}+\mathrm{Mg})$ was also a determinant of seedling and sapling communities.
\end{abstract}

KEYWORDS: Brazil; diversity; riparian forest; soils; tropics.

\section{Determinantes ambientais para regeneração natural de mata de galeria na transição Cerrado/Amazônia no Brasil}

\section{RESUMO}

Foi estudada a regeneração natural e a estrutura de três seçóes de uma floresta de galeria no leste de Mato Grosso, Brasil $\left(14^{\circ} 43^{\prime} \mathrm{S}\right.$ e $\left.52^{\circ} 21^{\prime} \mathrm{W}\right)$. O objetivo foi analisar a estrutura da floresta e verificar a relação entre a distribuição e abundância das espécies nos diferentes estágios de regeneração e entre as variáveis ambientais. Em cada seção de floresta foram estabelecidas, sistematicamente, 47 parcelas $(10 \times 10 \mathrm{~m})$ contíguas e permanentes para amostrar as árvores $(\mathrm{CAP} \geq 15 \mathrm{~cm})$. As plântulas jovens $(0,01 \mathrm{a} 1 \mathrm{~m}$ de altura), as plântulas maiores $(1,01 \mathrm{a} 2 \mathrm{~m})$ e as arvoretas (de $2,01 \mathrm{~m}$ de altura a CAP $\geq 15 \mathrm{~cm}$ ) foram amostradas em sub-parcelas de $1 \times 1 \mathrm{~m}, 2 \times 2 \mathrm{~m}$ e $5 \times 5 \mathrm{~m}$, respectivamente. Para cada parcela foram determinadas as propriedades do solo, projeção das clareiras, cobertura de bambus, rochosidade, declividade e profundidade do lençol freático. A relação das variáveis ambientais com as árvores e comunidades de plântulas e arvoretas foi determinada a partir de uma análise de correspondência canônica. Apesar das seções de floresta serem próximas entre si, apresentaram diferenças importantes em relação à composição florística, estrutura e variáveis ambientais. Os solos apresentaram reduzida capacidade de troca catiônica e elevados níveis de saturaçáo de alumínio. A ocorrência de bambus e clareiras e a profundidade do lençol freático limitam a ocorrência de arvoretas e árvores. A elevada heterogeneidade estrutural em cada categoria de regeneraçáo esteve relacionada principalmente a um gradiente de umidade, mas a fertilidade do solo $(\mathrm{Ca}+\mathrm{Mg})$ também foi determinante nas diferentes comunidades de plântulas.

PALAVRAS-CHAVE: diversidade; floresta ripária; solos; trópicos

\footnotetext{
1 Universidade do Estado de Mato Grosso - UNEMAT, E-mail: biamarimon@hotmail.com

2 Universidade de Brasilia - UnB, E-mail: jeanine.felfili@pq.cnpq.br

3 Universidade do Estado de Mato Grosso - UNEMAT, Campus de Nova Xavantina, E-mail: edsolima@hotmail.com

${ }^{4}$ Universidade do Estado de Mato Grosso - UNEMAT, Campus de Nova Xavantina, E-mail: biamarimon@yahoo.com.br

${ }^{5}$ Universidade do Estado de Mato Grosso - UNEMAT, Campus de Nova Xavantina, E-mail: bhmjunior@gmail.com
} 


\section{INTRODUCTION}

The typical landscape of Central Brazil consists of cerrado on the well-drained interfluves, with gallery forests following the watercourses (Ratter et al., 1997). Gallery forests, which are narrow strips of evergreen or semideciduous mesophytic forests (Ratter et al., 1973), are theoretically protected by law due to their important function in water and wildlife conservation (Oliveira-Filho et al., 1990; Paula-Lima \& Zakia, 2000). Nevertheless, often people clear them for subsistence cultivation or shelter for cattle (Felfili, 1997). These forests protect water quality, perform critical functions in both hydrological and biogeochemical cycles and also are widely recognized for their social and recreational values (Rodewald \& Bakermans, 2006).

Gallery forests contain c. 30\% of the species already listed for the Cerrado biome (Felfili et al., 2000) and represent refugia for species from the Atlantic, Amazon and the Paraná basin river forests plus endemic species (Oliveira-Filho \& Ratter, 1995).

At the boundaries between the Cerrado and Amazonia biomes, the gallery forests present several species in common with those forests. The same happens in places farther east where common species are found among the Atlantic forests but in the center of the biome a greater number of common species are found between gallery forests and the southern forests of the Paraná river basin. There is little similarity with the dominant savanna physiognomies of the Cerrado biome (Felfili \& SilvaJúnior, 1992). Meave et al. (1991) regarded them as present day refugia for moist forest species within the savanna dominium. According to Felfili (1997), gallery forests are vulnerable to the influence of external factors such as recurrent fires coming from the neighbouring cerrado formations.

Several surveys have been conducted (Ratter et al., 1973; Oliveira-Filho \& Martins, 1986; Oliveira-Filho et al., 1990; Felfili, 1995, 1997, 2000; Silva-Júnior et al., 1996, 2001; Marimon et al., 2001, 2002) in gallery forests but most on just single occasions. Felfili (1995, 1997, 2000), Sevilha (1999) and Miguel \& Marimon (2008) have been monitoring permanent sample plots. Their studies have shown that the abundant species regenerate the most in undisturbed forests. Pioneer species occur at higher densities in burned and disturbed environments, especially in gaps. Distinct dry and wet communities were also distinguished in those studies. The differentiation was so great that two tracts of well-drained soils in different forests were more similar between themselves than a dry and wet tract in the same forest (Sampaio et al., 2000). In this study we expect to distinguish different tree communities related to environmental gradients. The assumption is that these communities are selfregenerative with the abundant species regenerating the most and that environmental conditions are constraints to natural regeneration at later stages.
The objective was to compare the structure of the forest regarding natural regeneration (seedlings, saplings and poles) and adult trees; analyze whether the species are regenerating; and whether there is any relationship between species abundance at different stages of development and environmental variables in a gallery forest at the transition zone between the Cerrado and Amazonian biomes.

\section{METHODS}

\section{STUDY SITE}

This study was carried out in three sections (upper, middle and lower) of the gallery forest alongside the Bacaba stream in the Biological Reserve "Bacaba Park" (14\%43' S and 52 $21^{\prime}$ W), in Nova Xavantina, Mato Grosso, Brazil (Figure 1). The Reserve covers approximately $500 \mathrm{ha}$; the average altitude is $346 \mathrm{~m}$; and the climate is Aw by Köppen, with annual precipitation from 1300 to $1500 \mathrm{~mm}$ and a mean monthly temperature of $25^{\circ} \mathrm{C}$ according to the climatological station of Nova Xavantina.

The main physiognomy in the Reserve is the cerrado sensu stricto (savanna woodland) (Marimon et al., 1998) but there are areas covered with Campo (grasslands), Cerradão (dense savanna woodland) (Marimon-Júnior \& Haridasan, 2005; Abad \& Marimon, 2008) and a gallery forest, alongside the Bacaba stream (Marimon et al., 2001, 2002). At the sections of this gallery forest with higher altitude and declivity Litosols predominates with the presence of rocky outcrops whereas alluvial soils occur where the relief is less steep.

Three forest sections were selected within an extension of $1 \mathrm{~km}$ alongside the Bacaba stream covering the topographic gradient (Figure 1). The upper section is characterized by the presence of quartzite rocks, litosols, and a waterfall $(10 \mathrm{~m}$ high) in the rainy season; during strong rains, the streambed overflows, but the drainage is, in general, rapid. The middle section is also rocky and the soils are litosols, but the declivity is smaller. In this section, in the steeper sites, the conditions are similar to the upper, but on shallower sloping sites and, during the rainy season, the watertable flows over the surface. Rocks are absent in the lower section; the soils are alluvium and the relief is flat; the soil drainage is poor and the watertable either flows or remains close to the surface most of the year (Marimon et al., 2001, 2002).

\section{VEGETATION INVENTORY AND ENVIRONMENTAL VARIABLES}

In each section of the gallery forest, 47 contiguous permanent plots $100 \mathrm{~m}^{2}(10 \mathrm{~m} \times 10 \mathrm{~m})$ were established, following a systematic design (Philip, 1994), giving a total sampling area of $1.41 \mathrm{ha}$. These plots were allocated perpendicularly to the stream, going from the streambanks to the forest edges according to the methodology proposed by Felfili (1995). All trees and lianas with girth at breast height 


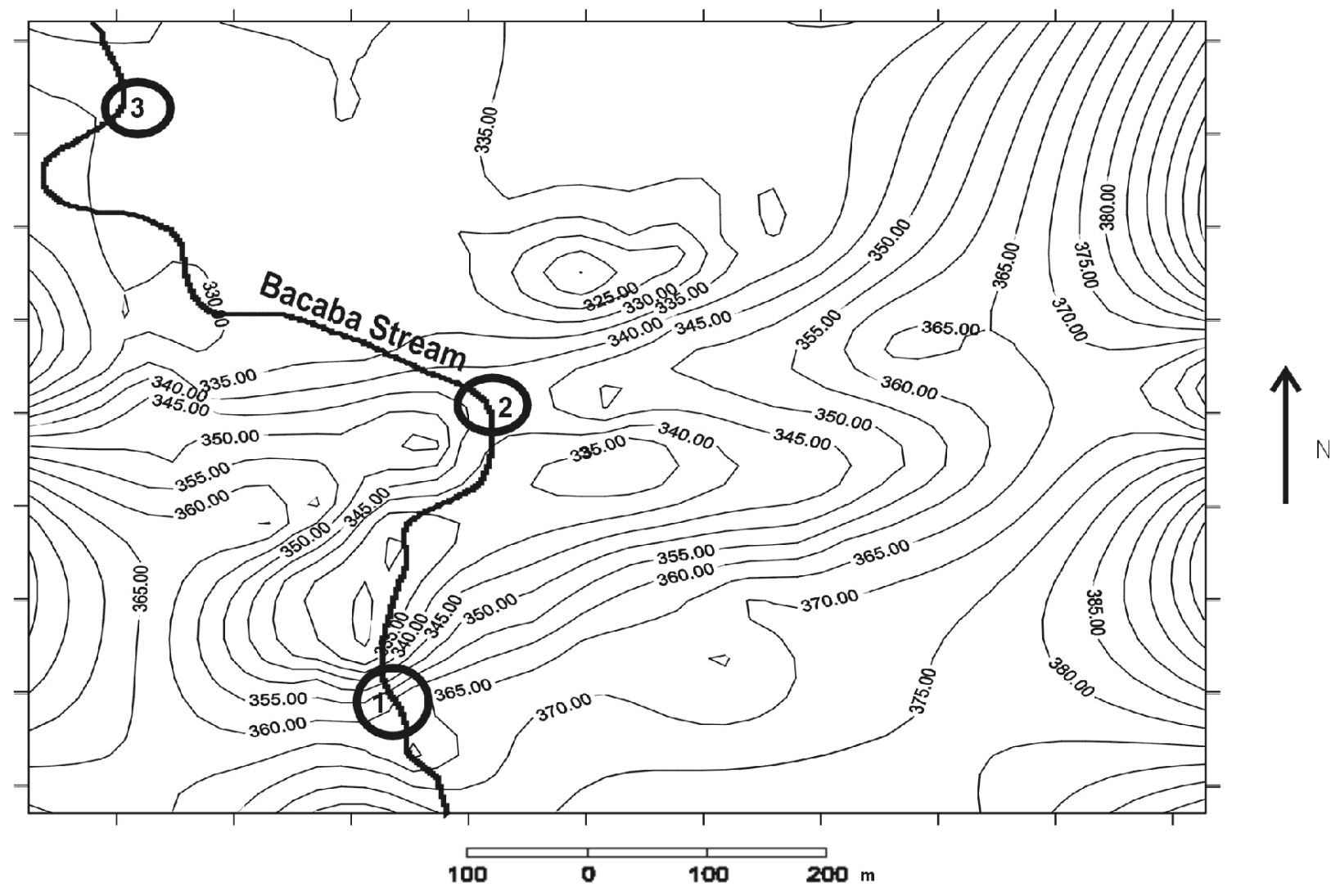

Figure 1 - Location of the study site at the Bacaba gallery forest, Nova Xavantina, Mato Grosso, Brazil. Upper (1), middle (2) and lower (3) sections.

(gbh) $\geq 15 \mathrm{~cm}$ were labeled with permanent aluminum tags, identified and measured (total height and gbh).

Each $100 \mathrm{~m}^{2}$ plot contained sub-plots for sampling the natural regeneration that was classified according to the stage of development of the individuals according to Felfili (1997): seedlings ( 0.01 to $1 \mathrm{~m}$ height), saplings ( 1.01 to $2 \mathrm{~m}$ ) and poles $(2.01 \mathrm{~m}$ height to $\mathrm{gbh}<15 \mathrm{~cm})$. They were sampled in sub-plots of $1 \times 1 \mathrm{~m}, 2 \times 2 \mathrm{~m}$ and $5 \times 5 \mathrm{~m}$, respectively. The total height of seedlings, saplings and poles were measured.

In each sampled plot $(10 \times 10 \mathrm{~m})$, gap projections (Brokaw, 1982) on the soil were measured and registered. Bamboo and grass, typical of degraded sites in gallery forests (Oliveira-Filho et al., 1994b; Felfili, 1997) and rocky cover were recorded and the declivity was measured in each plot with a clinometer. The level of ground watertable was measured at weekly intervals with $5 \mathrm{~cm}$ diameter perforated PVC tubes, which had been inserted into $1 \mathrm{~m}$ deep auger holes. Averages of the level of ground watertable in the rainy (November to March) and dry (May to September) seasons were obtained for each two adjacent plots.

A single 0.51 soil sample was collected from $0-10 \mathrm{~cm}$ depths, at the center of each plot. Granulometric and chemical analyses of the samples were made at the Soil Laboratory of the Agronomy Faculty at the Federal University of Mato Grosso. Laboratory procedures followed that of EMBRAPA (1997). Phosphorus and potassium were extracted with Mehlich solution $\left(\mathrm{HCl} 0.05 \mathrm{~N}+\mathrm{H}_{2} \mathrm{SO}_{4} 0.025 \mathrm{~N}\right)$, P was measured with a colorimeter and $\mathrm{K}$ with a photometer. Calcium plus magnesium and aluminium were extracted with a $1 \mathrm{~N} \mathrm{KCl}$ solution. Aluminium was titrated with $\mathrm{NaOH} 0.025 \mathrm{~N}$ solution, while $\mathrm{Ca}+\mathrm{Mg}$ were titrated with EDTA $0.025 \mathrm{~N}$. Soil $\mathrm{pH}$ was measured with a potentiometer in a $1: 2.5$ soil/ water suspension. Organic matter was determined by the Walkley-Black method (Tan, 1996). Texture was obtained by the densimetric Bouyoucos method.

\section{DATA ANALYSIS}

Species densities (Mueller-Dombois \& Ellenberg, 1974) were calculated and compared. The average number of individuals, number of gaps, the cover of bamboos and rocks, declivity, depth of ground watertable per plot and soil properties were compared between the sections. These analyses were carried out using the Program SAS v. 8.1 (SAS, 19992000), using Kruskal-Wallis test. 
Canonical correlation was used to investigate the relationships between the number of individuals in each regeneration categories (seedlings, saplings, poles and trees) and environmental variables in the plots. The matrix of environmental variables per plot initially included the number of gaps, bamboos and rocky covers, declivity, level of ground watertable in the rainy and dry seasons and all the chemical and physical soil properties described in Table 1 . The relationships between variables were examined to ensure approximate normality, linearity and to find outliers (Tabachnick \& Fidell, 2001). After a preliminary analysis (SAS, 1999-2000), seven environmental variables were eliminated due to either high redundancy or poor correlation.

Trees and seedlings were used to analyse the relationship between them and environment, because they represent two extreme groups regarding plant development. Trees represent established plants, and seedlings represent the most immediate group after reproduction. For each category (trees and seedlings) two input matrixes were used. The species matrix contained the density per plot for those with more than eight individuals in the total sample. For trees, the matrix had 50 species per 140 plots and for seedlings, 22 species per 104 plots. The environmental matrix contained the values of 16 environmental variables. After preliminary analyses, we eliminated all variables with low correlation with the first two ordination axes $(<0.4)$, and the final analysis was performed with five environmental variables. The program CANOCO 4 (Ter Braak \& Smilauer, 1998) was used to perform CCA and the graphs were drawn using CANODRAW 3.0 (Smilauer, 1992).

\section{RESULTS}

\section{ENVIRONMENTAL GRADIENTS AND FLORISTIC COMPOSITION}

Soil $\mathrm{pH}$ in water, $\mathrm{P}, \mathrm{K}, \mathrm{Ca}+\mathrm{Mg}$ and $\mathrm{Al}$ showed significant differences between forest sections (Table 1). The $\mathrm{pH}$ in water ranged from strongly acidic (4.1), in the lower section, to mean acidic (5.3), in the upper. The soil of most plots (61\%) was very acidic $(<5)$ with a high $\mathrm{Al}$ content. Phosphorus was very low in the upper and lower section. The content of macronutrients was always higher in the middle section, which had moderate $\mathrm{Al}$ toxic levels for cultivated plants and also higher $\mathrm{P}$ contents compared to the other two sections. Organic matter and soil texture showed no significant difference. Texture was sandy in the three sections of the forest with clay contents under 15 percent. Soil features were highly variable (Table 1).

The number of gaps were similar at the tree sections, they ranged from $15 \mathrm{~m}^{2}$ to $20 \mathrm{~m}^{2}$ being typically small gaps. Watertable level were much closer to the surface at the lower section than the others, both during the rainy and dry season. At the lower section bamboo cover and declivity were very low and rocks were absent. At the upper sections, bamboo cover was twice as high as the middle sections, while rock cover was the opposite. Therefore, humidity and the physical barriers to regeneration imposed by declivity, rock and bamboo cover constituted the main physical gradients (Table 2).

A total of 137 species of 110 genera in 50 families were sampled in the three sections of the forest. Tetragastris altissima (Aubl.) Swart., Bauhinia outimouta Aubl. (liana) and Pouteria gardneri (Mart. \& Miq.) Baehni were the only species common to the three sites and were found in all regeneration categories. Only 25 percent of the 129 species found as trees did not have juveniles in any category of regeneration. Species richness increased from saplings, to seedlings, poles and trees (Table 3).

\section{STRUCTURE}

A total of 58 of the 129 species found as trees did not have any seedlings. However, 62 species had saplings and 84 had poles in at least one section of the forest. The Pearson's correlation between the density of trees and

Table 1 - Chemical and physical properties of the soil at the upper, middle and lower sections of the Bacaba gallery forest, Nova Xavantina-MT, Brazil. Mean (and Standard Deviation) of 47 samples in each forest section and probabilities of the Chi-square between the sections (Kruskal-Wallis test).

\begin{tabular}{|c|c|c|c|c|c|}
\hline Properties & Upper & Middle & Lower & Chi-square & $P$ \\
\hline \multicolumn{6}{|c|}{ Chemical: } \\
\hline $\mathrm{pH}$ in water & $4.7(0.78)$ & $5.3(0.31)$ & $4.1(0.15)$ & 75.103 & $<0.0001$ \\
\hline $\mathrm{pH}$ in $\mathrm{CaCl}_{2}$ & $3.4(0.28)$ & $3.6(0.70)$ & $3.3(0.16)$ & 4.688 & 0.0959 \\
\hline $\mathrm{P}\left(\mathrm{mg} / \mathrm{dm}^{3}\right)$ & $0.87(1.54)$ & $6.98(11.73)$ & $1.71(2.88)$ & 13.370 & 0.0012 \\
\hline $\mathrm{K}\left(\mathrm{mg} / \mathrm{dm}^{3}\right)$ & $52.85(46.51)$ & $76.74(33.76)$ & $43.87(27.05)$ & 29.378 & $<0.0001$ \\
\hline $\mathrm{Ca}+\mathrm{Mg}\left(\mathrm{cmol}_{\mathrm{c}} / \mathrm{dm}^{3}\right)$ & $1.54(0.78)$ & $2.85(2.92)$ & $1.27(0.32)$ & 15.830 & 0.0004 \\
\hline $\mathrm{Al}\left(\mathrm{cmol}_{\mathrm{c}} / \mathrm{dm}^{3}\right)$ & $1.34(0.46)$ & $0.94(0.60)$ & $1.46(0.35)$ & 21.184 & $<0.0001$ \\
\hline Organic Material $\left(\mathrm{g} / \mathrm{dm}^{3}\right)$ & $5.39(3.56)$ & $5.91(2.69)$ & $5.56(2.91)$ & 4.186 & 0.1233 \\
\hline \multicolumn{6}{|c|}{ Physical: Texture $(\mathrm{g} / \mathrm{Kg})$} \\
\hline Sand & $782.3(104.18)$ & $835.3(58.52)$ & $802.3(85.62)$ & 5.847 & 0.0537 \\
\hline Silt & $68.1(24.81)$ & $61.1(20.97)$ & $70.4(15.60)$ & 5.437 & 0.0660 \\
\hline Clay & $149.6(91.34)$ & $103.6(52.06)$ & $127.3(80.77)$ & 5.930 & 0.0515 \\
\hline
\end{tabular}


Table 2 - Average number of gaps, cover of bamboos (\%), rocks (\%), declivity (\%), and depth of ground watertable (cm) in the rainy and dry seasons per plots of the Bacaba gallery forest, Nova Xavantina-MT, Brazil. Mean (and Standard Deviation) of 47 samples in each forest section and probabilities of the Chi-square between the sections (Kruskal-Wallis test).

\begin{tabular}{lccccc}
\hline & Upper & Middle & Lower & Chi-square & P \\
\hline \multicolumn{5}{c}{ Nr. or depth $(\mathrm{cm})$ per plot } \\
\hline Gaps & $0.82(0.70)$ & $0.89(0.66)$ & $1.00(0.75)$ & 1.233 & 0.5397 \\
Water table (rain) & $91.98(37.47)$ & $81.06(38.11)$ & $39.96(24.42)$ & 43.127 & $<0.0001$ \\
Water table (dry) & $>100$ & $>100$ & $82.36(29.11)$ & 55.566 & $<0.0001$ \\
\hline \multicolumn{7}{c}{ Percentage per plot } \\
\hline Bamboos & $14.64(17.27)$ & $7.10(8.22)$ & $1.61(4.27)$ & 29.981 & $<0.0001$ \\
Rocks & $7.42(8.77)$ & $13.70(11.69)$ & 0.00 & 91.994 & $<0.0001$ \\
Declivity & $41.11(18.46)$ & $31.62(18.83)$ & $4.85(5.51)$ & 78.318 & $<0.0001$ \\
\hline
\end{tabular}

Table 3 - Total of individuals (individuals/ha) of seedlings (Se), saplings (Sa), poles (P) and trees (or lianas) $(\mathrm{T})$ at the upper, middle and lower sections of the Bacaba gallery forest, Nova Xavantina-MT, Brazil. Pearson's correlation between each regeneration category and trees.

\begin{tabular}{|c|c|c|c|c|c|c|c|c|c|c|c|c|}
\hline \multirow{2}{*}{ Parameters } & \multicolumn{4}{|c|}{ Upper } & \multicolumn{4}{|c|}{ Middle } & \multicolumn{4}{|c|}{ Lower } \\
\hline & Se & $\mathrm{Sa}$ & $P$ & $\mathrm{~T}$ & Se & $\mathrm{Sa}$ & $P$ & $\mathrm{~T}$ & Se & $\mathrm{Sa}$ & $P$ & $T$ \\
\hline Total of individuals & 38781 & 3719 & 1593 & 965 & 47661 & 7131 & 2877 & 938 & 40211 & 3396 & 2501 & 1257 \\
\hline Total of species & 43 & 36 & 55 & 74 & 38 & 29 & 59 & 86 & 41 & 25 & 57 & 77 \\
\hline Pearson's correlation & 0.73 & 0.68 & 0.56 & & 0.45 & 0.65 & 0.58 & & 0.13 & 0.28 & 0.59 & \\
\hline
\end{tabular}

poles varied from 0.56 to 0.59 at the three forest sections, suggesting that the future forest composition and structure will be maintained with some fluctuations and that there is a positive correlation between density of trees and density of juveniles (poles) (Table 3). Most species occurred at low densities. Tetragastris altissima, with 11,064 seedlings and 1,542 saplings/ha at the middle section was the most abundant species. Ephedranthus parviflorus S. Moore, with $374 \mathrm{ind}$./ha in the middle section, had the most poles, while Cecropia pachystachya Tréc., a pioneer species (Felfili, 1995), presented the highest number of trees (126 ind./ha) in the lower section. Some species, which were abundant as trees, had little or no regeneration, such as $C$. pachystachya; and some species abundant as seedlings or saplings (Erythroxylum daphnites Mart., Copaifera langsdorffii Desf. and Myrcia tomentosa (Aubl.) DC.) had few trees.

The structure of the forest community as a whole is shown in the Figure 2, and the population structure of the most important species (Marimon et al., 2002) in each forest section is shown in Figure 3. Mauritia flexuosa L., a palm tree indicator of swampy sites, had a high density at all stages in the lower section, while Diospyros obovata Jacq. was abundant only as seedlings in the upper, and Hymenaea courbaril L. var. stilbocarpa (Hayne) Lee \& Langenheim had a large number of large trees (i.e. $\mathrm{gbh}=215 \mathrm{~cm}$ ) at the middle.

\section{SPECIES X ENVIRONMENTAL GRADIENTS}

Seedlings, saplings and poles were more abundant in the middle, and the number of trees was higher in the lower (Table 3).

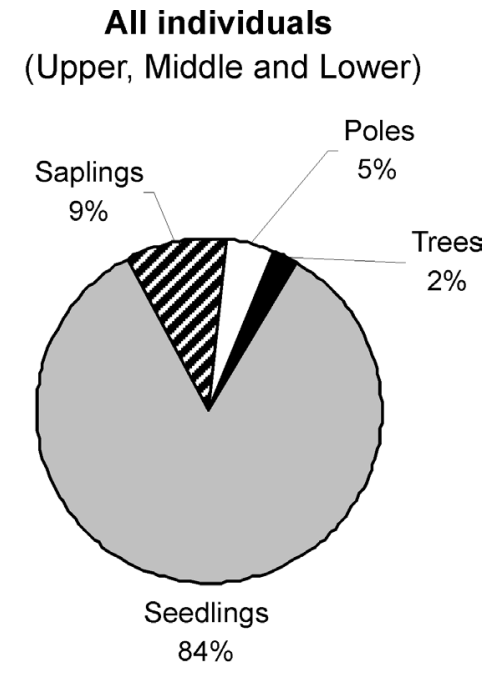

Figure 2 - Community structure of the Bacaba gallery forest in Nova XavantinaMT, Brazil.

The first canonical correlation (regeneration categories $v$ s. environmental variables) was 0.689 (c. $47 \%$ overlapping variance, $F=4.25$ and $P<0.0001)$, the second was 0.511 ( $c$. $26 \%$ overlapping variance, $F=2.37$ and $P=0.0004)$ and the eigenvalue explained c. $90 \%$ of the variance. Data on the first two pairs of canonical variates are in Table 4.

Considering a 0.3 cutoff correlation (Tabachnick \& Fidell, 2001), the first pair of canonical variates had high loadings for poles and trees regarding the regeneration categories and for $\mathrm{pH}$ in water, declivity, clay, bamboos, gaps and depth of ground watertable in the dry season regarding the 


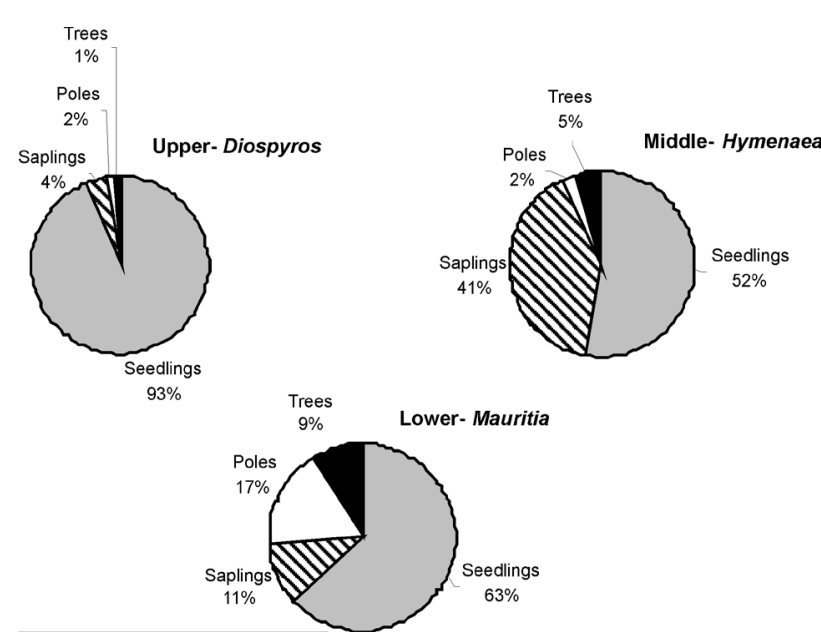

Figure 3 - Population structure of Diospyros obovata (main species of the forest upper section), Hymenaea courbaril (middle) and Mauritia flexuosa (lower) at the Bacaba gallery forest, Nova Xavantina-MT, Brazil.

Table 4 - Correlations and percents of variance between regeneration categories and environmental variables and their corresponding canonical variates in the sections of the Bacaba gallery forest, Nova Xavantina-MT, Brazil.

\begin{tabular}{|c|c|c|c|}
\hline & $\begin{array}{l}\text { First Canonical } \\
\text { Variable }\end{array}$ & $\begin{array}{c}\text { Second Canonical } \\
\text { Variable }\end{array}$ & \\
\hline & Correlation & Correlation & \\
\hline \multicolumn{4}{|c|}{ Regeneration Categories } \\
\hline Seedlings & -0.0204 & 0.3809 & \\
\hline Saplings & 0.0714 & 0.7360 & \\
\hline Poles & -0.4689 & 0.7951 & \\
\hline Trees & -0.9584 & -0.1386 & \\
\hline Variance & $28.60 \%$ & $33.45 \%$ & Total $=62.05 \%$ \\
\hline Redundancy & $13.59 \%$ & $8.76 \%$ & Total $=22.35 \%$ \\
\hline \multicolumn{4}{|c|}{ Environmental Variables } \\
\hline pHwater & 0.3650 & -01083 & \\
\hline Al & -0.2022 & -0.6840 & \\
\hline $\mathrm{Ca}+\mathrm{Mg}$ & 0.2978 & 0.5320 & \\
\hline Bamboos & 0.7186 & 0.0359 & \\
\hline Gaps & 0.6244 & -0.4231 & \\
\hline $\begin{array}{l}\text { Watertable (dry } \\
\text { season) }\end{array}$ & 0.5509 & -0.0514 & \\
\hline Clay & 0.4329 & -0.1029 & \\
\hline Declivity & 0.3012 & 0.2028 & \\
\hline Organic matter & 0.0534 & -01833 & \\
\hline Variance & $20.22 \%$ & $11.45 \%$ & Total $=31.67 \%$ \\
\hline Redundancy & $9.61 \%$ & $3.00 \%$ & Total $=12.61 \%$ \\
\hline $\begin{array}{l}\text { Canonical } \\
\text { correlation }\end{array}$ & 0.6893 & 0.5116 & \\
\hline
\end{tabular}

environmental variables (Table 4). Thus, low densities of poles and trees were related to high $\mathrm{pH}$ in water, declivity, clay levels, bamboo cover, gaps number and high depth of ground watertable in the dry season.

The second pair of canonical variates had high loadings for seedlings, saplings and poles of the regeneration categories and
$\mathrm{Al}, \mathrm{Ca}+\mathrm{Mg}$ and gaps for the environmental side (Table 4). A high density of seedlings, saplings and poles were related to a small number of gaps, low $\mathrm{Al}$ and high $\mathrm{Ca}+\mathrm{Mg}$ levels.

The first canonical variate extracted $28.60 \%$ of variance from the regeneration categories and $20.22 \%$ of variance from the environmental variables. The second canonical variate pair extracted $33.45 \%$ of variance from the regeneration categories and $11.45 \%$ of variance from the environmental variables.

Together, two environmental variable variates "explained" $22.35 \%$ of the variance in the regeneration categories. The first regeneration category variate accounted for $9.6 \%$ and the second for $3 \%$ of the variance in the environmental set of variables (Table 4).

The environmental variables were, apparently, enough to explain most of the species abundance distribution as shown by the CCA results (comparing density of the species for trees and seedlings with six environmental variables) (Figure 4a) with eigenvalues of the first and second axis, of 0.545 and 0.444 . The species-environment correlations yielded by these axes were 0.823 and 0.720 , and their cumulative percentage variances were 32.5 and $58.9 \%$. This was reinforced by the Monte Carlo test $(F=3.55, P<0.01)$ that indicated a significant correlation between environmental variables and the species abundance distribution. For correlations among environmental variables and trees (Figure $4 \mathrm{~b}$ ), the eigenvalues of the first and second axis, were 0.479 and 0.340 . The species-environment correlations yielded by these axes were 0.850 and 0.799 and their cumulative percentage variances were 43.8 and $75 \%$. These values and the result of the Monte Carlo test $(F=4.02, P<0.01)$ also indicated a highly significant correlation between environmental variables and species abundance distribution.

For seedlings (Figure 4a), the first axis was mainly correlated to topographic features [declivity $(-)$ ] and levels of $\mathrm{Al}(+)$. The second axis was best correlated to $\mathrm{Ca}+\mathrm{Mg}$ levels $(+)$ and a humidity gradient (distance from the stream and watertable depth). The most distinct group was formed by the plots of the lower section (lowest declivity, lowest watertable depth and highest $\mathrm{Al}$ saturation). Species distribution was wider along the second axis compared to the first and, apparently, their distribution was mainly related to humidity and macronutrients $(\mathrm{Ca}+\mathrm{Mg})$ gradients. Astronium fraxinifolium Schott. seedlings were related to soils with more $\mathrm{Ca}+\mathrm{Mg}$ at the middle section of the forest while Mauritia flexuosa seedlings occurred in the lower section where the relief is flat, the watertable remains close to the surface most of the year, soil is acidic and nutrient poor.

For trees (Figure 4b), the first axis was best correlated to a humidity gradient [distance from the stream $(+)$ and watertable depth $(+)]$ and the second axis was mainly correlated to declivity (-). The plots of the lower section 

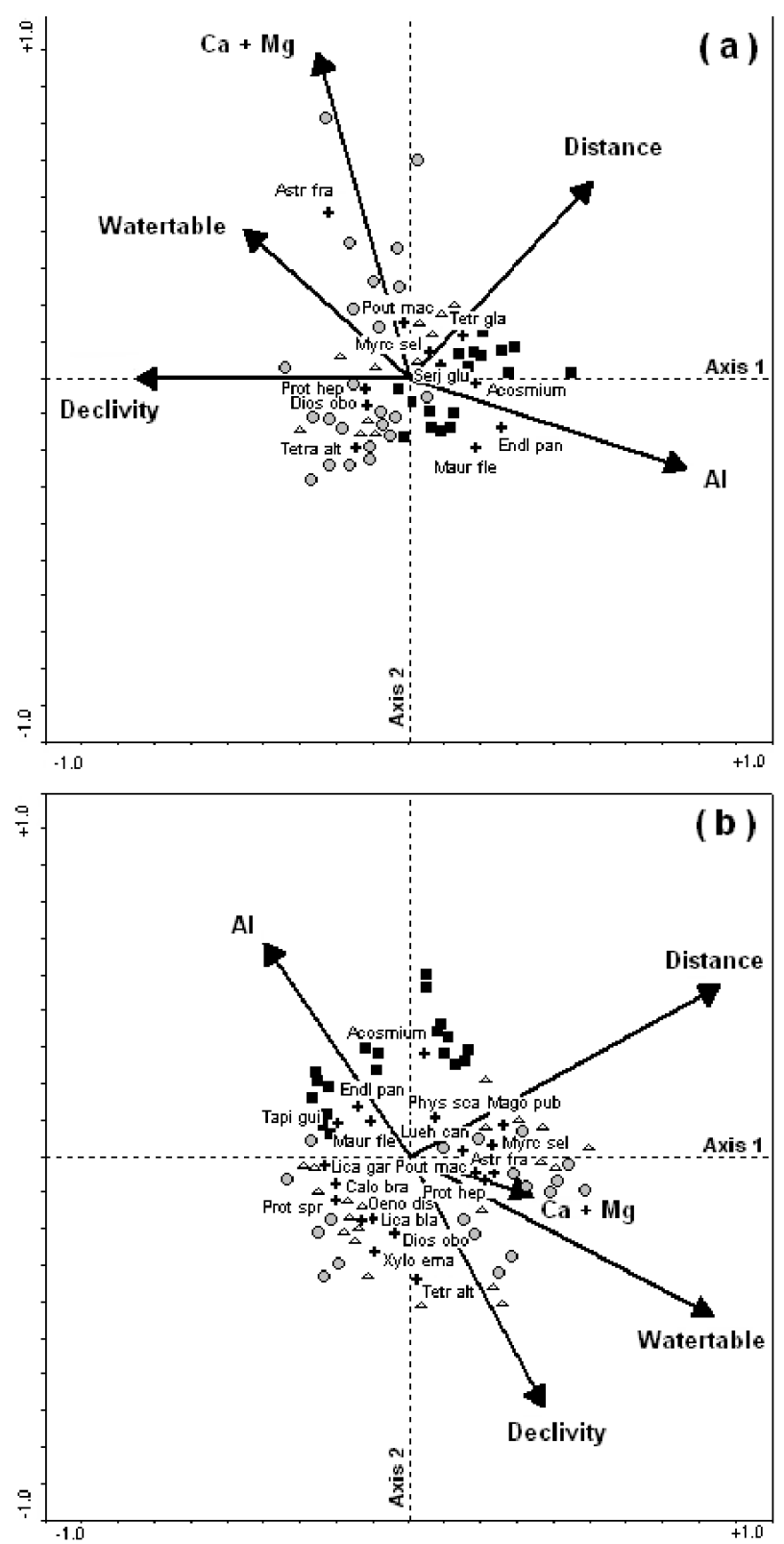

Figure 4 - Ordination diagrams produced by Canonical Correspondence Analyses (CCA) of the 141 plots based on the number of individuals per plot of the species of trees and seedlings ( $\geq 8$ individuals) and 16 environmental variables. The diagrams show the CCA for seedlings (a) and trees (b) species and environmental variables. The forest sections are identified by: triangle (upper), circle (middle) and square (lower). Species are identified by their abbreviated names (Astronium fraxinifolium Schott., Calophyllum brasiliense Cambess, Diospyros obovata Jacq., Endlicheria paniculata (Spreng.) Macbr., Licania blackii Prance, Licania gardneri (Hook. f.) Fritsch, Luehea candicans Mart., Magonia pubescens St. Hil., Mauritia flexuosa L., Myrcia sellowiana Berg, Oenocarpus distichus Mart., Ormosia excelsa Benth. (Acosmium in the figure), Physocalymma scaberrimum Pohl, Pouteria gardneri (Mart. \& Miq.) Baehni (Pout mac in the Figure), Protium heptaphyllum (Aubl.) March., Protium spruceanum (Benth.) Engl., Serjania glutinosa Radlk., Tapirira guianensis Aubl., Tetragastris altissima (Aubl.) Swart., Tetrapterys glabra (Spreng.) Griseb., Xylopia emarginata Mart.) The diagrams use the same scale. were clearly separated from those from the high and middle sections. They were mainly related to topographic variables. Species distribution was wider along the second axis compared to the first, reflecting a topographic gradient. Ormosia excelsa Benth., Endlicheria paniculata (Spreng.) Macbr. and Mauritia flexuosa trees were related to the lower section and Xylopia emarginata Mart., Diospyros obovata Jacq. and Licania blackii Prance to the upper and middle sections.

Some species showed a similar pattern at both stages, seedlings and trees, such as Diospyros obovata found in both stages mostly at the upper and middle sections, on the steepest sites nearer to the streambank; Mauritia flexuosa and Ormosia excelsa had most seedlings and trees individuals at the lower, flatter, swampy sites with high Al content. Seedlings of Tetragastris altissima occurred mostly in sites near to the streambank but the trees were on the steepest sites.

\section{DISCUSSION}

\section{ENVIRONMENTAL GRADIENTS AND FLORISTIC COMPOSITION}

The acidic $\mathrm{pH}$ in water showed values within the range found by Haridasan \& Araújo (1988), Felfili (1995), SilvaJúnior et al. (1996) and Delitti \& Burger (2000), for gallery forests. The wet community soils (lower section, see level of ground watertable in Table 2) showed lower $\mathrm{pH}^{\prime}$ s (Table 1) when compared with the upper and middle sections while $\mathrm{Al}$ levels had the opposite trends. Silva-Júnior et al. (1996) also observed that the wet community soils showed a lower $\mathrm{pH}$ in gallery forests of Central Brazil. The increasing acidity towards the lower section is probably related to a corresponding increase in soil moisture. Las Salas (1987) observed that high soil moisture favours organic matter decomposition and the release of $\mathrm{CO}_{2}$, which acidifies the soil by reacting with water.

The middle section is richer in mineral nutrients $(\mathrm{P}, \mathrm{K}$, $\mathrm{Ca}+\mathrm{Mg}$ ) than the upper and lower sections. Hornung (1990) also observed that upper topographic areas, in general, are poorer in most mineral nutrient than lower areas because of differential erosion. Nutrients are probably lost from the upper to the middle section, where the drainage is rapid. The lower section was the poorest in $\mathrm{P}, \mathrm{K}$ and $\mathrm{Ca}+\mathrm{Mg}$ probably due to swampy conditions that favour a low $\mathrm{pH}$. Mineral elements are immobilized by free $\mathrm{Al}$ found under low $\mathrm{pH}$ (Furley \& Ratter, 1988; Brady \& Weil, 1996). P levels were very low (CFSEMG, 1978), but within the levels found for other gallery forests (Felfili, 1995; Silva-Júnior et al., 1996).

Some indicator species of richer soils according to Askew et al. (1971) such as Sterculia striata St. Hil. \& Naud., Vitex polygama Cham., Dilodendron bipinnatum Radlk., among others, were found in the middle section with higher content of $\mathrm{Ca}+\mathrm{Mg}$. Patches of fertile soils can be found within Central 
Brazil where dystrophic soils predominate (Furley \& Ratter, 1988; Prado \& Gibbs, 1993) supporting dry seasonal forests in which those species predominate.

The aluminium contents in the study area are high, reaching levels considered toxic for cultivated plants (Araújo $\&$ Haridasan, 1988). Even though, gallery forest species seem to have mechanisms to cope with acidic and aluminium toxic soils as well as the species from the savanna physiognomies of the biome pointed by Furley \& Ratter (1988). The lowest figures for aluminium were found at the more fertile middle section where soil-rich indicator species were found.

Different soil types were found in the studied sections of this forest, supporting some studies in Central Brazil (Felfili, 1995; Silva-Júnior et al., 1996) showing the occurrence of gallery forests on a variety of soils other than the hydromorphic which are usually shown by regional soil mappings.

The absence of seedlings, saplings and poles of $25 \%$ of the species may be a reflection of an episodic pattern of regeneration as suggested by Clark \& Clark (1987) for some tropical species or to traits of their life history as shown by Felfili (1997) for gallery forest species. This author suggested that the Cecropia pachystachya, a pioneer species, do not form a seedling bank, as its seedlings either pass quickly from sapling to pole phase or die in a short time. However, seedlings and saplings of a more tolerant species, such as Copaifera langsdorffi, may remain for a long period under arrested development in the understorey, forming a seedling bank which is just developing into trees when the environmental conditions change by the formation of gaps. Hubbell \& Foster (1987) also found tropical species forming a seedling bank of species with arrested development under shade.

In this forest, some species were abundant as trees such as Cecropia pachystachya but had none or little natural regeneration, while others were rare as trees, such as Ouratea castaneaefolia (DC.) Engl., and were abundant as seedlings or saplings. The former, a pioneer, is probably loosing its importance in the forest, while the second, a shade tolerant (Felfili et al., 2000), is increasing.

The patterns found in the forests are determined by several environmental and genetic factors and their interaction. Hubbell (1979), Clark \& Clark (1987), Swaine \& Whitmore (1988) and Swaine (1989) suggested that differences in patterns of seed dispersion, reproductive systems, intensity and quality of light, root competition and predation probably play an important role on the maintenance of tree diversity in tropical forests. According to Felfili (1997) these variations play a substantial role in the maintenance of the structure and floristic composition of gallery forest communities, favouring different species at different times within the distinct microsites determined by forest dynamics and canopy layers (Medina, 1995). According to Kellman et al. (1994), the maintenance of local biotic diversity in gallery forests requires a diversity of alternative opportunities and coexisting assemblages of species and must be "nichespecialized" in some way. It is clear that some species such as Mauritia flexuosa are specialized on swampy sites in gallery forests and others such as Copaifera langsdorffii on more drained patches. These species may occur very near to each other but under completely different conditions regarding humidity and light. Gallery forests consist of a very complex environment containing a complex mosaic in a narrow area along the watercourse.

A large number of generalist species in this gallery forest (Xylopia aromatica (Lam.) Mart., Protium heptaphyllum (Aubl.) March., Tapirira guianensis Aubl., Siparuna guianensis Aubl., Tabebuia serratifolia (Vahl) Nichols, and others) at the transition Cerrado/Amazonia where there is contact among the main hydrographical basins of South America reinforce the role of these forests as ecological corridors, joining different physiographic units (Silva et al., 2006). These linkings through riparian corridors allowed past and current floristic contact as suggested by some studies (Pires \& Prance, 1977; Pinto \& Oliveira-Filho, 1999; Ivanauskas et al., 2003; Miguel \& Marimon, 2008) and continues to allow the gene flow through the Amazonian and Cerrado biomes.

The differences in the patterns of species richness (higher richness of trees than seedlings and saplings) found among the regeneration categories are probably related to the presence of many rare species as trees. Some may be disappearing from the forest while others may be entering it (Felfili, 1995, 1997) and their regeneration may be scarce or episodic. The dynamics of forest communities is very complex in time and space (Oliveira-Filho et al., 1994c) and fluctuation in diversity and structure over time have been registered (Felfili, 1995, 1997).

\section{STRUCTURE}

A much larger proportion of juveniles to trees (84\% seedlings, $9 \%$ saplings, $5 \%$ poles and $2 \%$ trees) was found in this study as shown in Figure 2. These figures suggest that only one of 42 seedlings becomes a mature tree at the Bacaba gallery forest. This concentration of density in juveniles is a trait of tropical forests (Whitmore, 1990) and a similar proportion (1:50) to those found here have also been registered for undisturbed gallery forests of Central Brazil (Felfili, 1997, 2000).

Some non-pioneer light demanding species, abundant as trees, such as Tetragastris altissima and Diospyros obovata were scarce as poles probably due to unfavorable light conditions for establishment. In gallery forests, the gaps are few and small under close canopy, a condition where less than $2 \%$ of solar radiation reach the understorey, that favours the 
regeneration of shade tolerants reducing then, the density of pioneers and species that demands light (Felfili, 1997; Felfili \& Abreu, 1999).

Mabea pohliana (Benth.) Muell. Arg. and Siparuna guianensis are small dimension understorey species (Felfili, 1997) that may reach maturity showing a smaller size than most species.

The population structure of the most abundant species varies with Diospyros obovata (upper) abundant as seedlings and trees, but scarce as saplings and poles (Figure 3). The seedlings form a dense grouping under the mother-tree with only a few saplings scattered around seeming to be survivors of a strong competition among the clustered seedlings as suggested by Brown \& Whitmore (1992) and Lieberman (1996) for some tropical plants. Hymenaea courbaril (the most important in the middle) had an abundance of saplings (Figure 3). Mauritia flexuosa (lower), a palm tree, was abundant at all regeneration stages with seedlings representing 60 percent of the total density in contrast to the current 10 percent of trees (Figure 3). Nascimento \& Hay (1990) and Felfili (1997) suggested that species presenting this pattern have stable, self-regenerating populations and will remain as important in the forest canopy.

Pearson's correlations indicated that the floristic composition and structure of the forest would be fairly similar in the future depending on the current pole population. For the upper and the middle, even the seedlings and saplings populations are fairly well correlated to the trees. The low correlation between seedlings, saplings and trees in the lower is probably due to the death of juveniles after germination during the early stages of establishment in those swampy sites.

\section{REGENERATION CATEGORIES AND ENVIRONMENTAL GRADIENTS}

The lower, wetter site had the highest density of trees per plot. In this site, the soil coverage by bamboos and rocks was smaller than in the others, the declivity was less accentuated and the ground watertable was closer to the surface. This result confirms that a high number of individuals is a trait of swampy gallery forests (Sampaio et al., 2000). Seedlings, saplings and poles were more abundant at the middle, where rocky cover was high but bamboos and slope were at an intermediary level. The high declivity of the upper probably cause seed loss by run off in the rainy season. The topographic gradient and the ground watertable level have a direct influence on the pattern of establishment and immigration of the species at each section of this forest. According to Kellman et al. (1994), these factors contribute to the maintenance of diversity in gallery forests once they favour high immigration rates.

High cover of bamboos, gaps and deep watertable in the dry season were inversely correlated to density of poles and trees, according to the first canonical variable. A higher competition and less water available at the surface are limiting to plant development. The second canonical variable showed that the presence of seedlings, saplings and poles was inversely correlated to gaps and Al but directly to higher $\mathrm{Ca}+\mathrm{Mg}$ levels. According to Whitmore (1984) and Oliveira-Filho et al. (1994b), bamboos, once established, can interfere with the tree community for long periods. Oliveira-Filho et al. (1998) observed that species distribution and abundance were correlated with both the relative area of canopy gaps and the soil-topography gradient, and suggested that the critical factors involved in these gradients are light and ground water regimes.

These correlations suggested that the physical structure (bamboos, gaps and ground watertable) is probably an important component in determining tree communities, while soil fertility $(\mathrm{Ca}+\mathrm{Mg})$ is an important component in determining seedling, sapling and pole communities.

The tree and seedling communities showed a continuous distribution of species, even though there were differences amongst the forest sections. The lower section turned out to be the most differentiated community (Marimon et al., 2001, 2002), leading to a particular set of species (trees and seedlings) with peculiar establishment strategies linked especially to a humidity gradient. These findings agree with those of Oliveira \& Felfili (2005) studies of natural regeneration of a gallery forest in Central Brazil.

In the Bacaba forest the seedlings and mature tree distribution were coincident for several species such as Mauritia flexuosa, an exclusive species of humid sites, indicating that some species are strongly associated to certain environmental conditions during all their life cycle.

Among the environmental variables that presented variations among the forest sections the most important were declivity, watertable depth and distance from the stream. Oliveira-Filho et al. (1994a) and Felfili (1995) found strong correlations between species distribution, soil variation and distance from the watercourse, suggesting that a humidity gradient is related to those physical features that determine species distribution.

The presence of indicator species of nutrient-rich sites such as Sterculia striata was determined by higher levels of P, $\mathrm{K}$ and $\mathrm{Ca}+\mathrm{Mg}$ at the middle section of the forest.

\section{ACKNOWLEDGMENTS}

We are grateful to the Foundation for Sponsor Research in Mato Grosso (FAPEMAT) for the research grant (Contract no. 2.01.00055/1998-05); to DFID-UK; to CNPq for the PQ Research grant to J.M. Felfili; and to CRAD-Universidade de Brasilía and INCT de Madeiras da Amazônia for their support; to several botanists, especially to Dr. James Alexander 
Ratter; to Claudonei das Neves Rosa, Adão Luiz Patrocínio, Adair José Rodrigues and Juvenal Pinheiro-Neto for field assistance; and to Dr. Christopher William Fagg for reviewing the manuscript.

\section{LITERATURE CITED}

Abad, J.C.S.; Marimon, B.S. 2008. Diagnóstico, Gestão e Expansão do Parque Municipal do Bacaba, Nova Xavantina-MT, pp. 23-56. In: Santos, J.E.; Galbiati, C. (Org). Gestão e Educação Ambiental: Água, Biodiversidade e Cultura, Ed. Rima, Vol. 1.

Araújo, G.M.; Haridasan, G.M. 1988. A comparison of the nutrient status of two forests on dystrophic and mesotrophic soils in the cerrado region of central Brazil. Communications in Soil Science and Plant Analysis, 19: 1075-1089.

Askew, K.P.; Montgomery, R.F.; Searl, P.L. 1971. Soil and soil moisture as factors influencing the distribution of the vegetation formations of the Serra do Roncador, Mato Grosso, p. 150-160. In: Ferri, M.G. (Ed). III Simpósio sobre o cerrado. Edgard Blücher/ EDUSP, São Paulo.

Brady, N.C.; Weil, R.R. 1996. The nature and properties of soils. Prentice Hall, Upper Saddle River, New Jersey, USA.

Brokaw, N.V.L. 1982. The definition of tree fall gap and its effect on measures of forest dynamics. Biotropica, 14: 158-160.

Brown, N.D.; Whitmore, T.C. 1992. Do dipterocarp seedlings really partition tropical rain forest gaps? Philosophical Transactions of the Royal Society of London Biological Sciences, 335: 369-378.

CFSEMg. 1978. Recomendaçöes para o uso de corretivos e fertilizantes em Minas Gerais - $3^{\text {a }}$ aproximação. EPAMIG, Belo Horizonte.

Clark, D.A.; Clark, B. 1987. Análisis de la regeneración de árboles del dosel en bosque muy húmedo tropical: aspectos teóricos y prácticos. Revista de Biologia Tropical, 35: 41-54.

Delitti, W.B.C.; Burger, D.M. 2000. Carbon and mineral nutrient pools in a gallery forest at Mogi Guaçú River, Southeast Brazil. Annals of Forest Science, 57: 39-47.

Embrapa. 1997. Manual de métodos de análises de solos. Centro Nacional de Pesquisa de Solos. Empresa Brasileira de Pesquisa Agropecuária (EMBRAPA), Rio de Janeiro, Brasil.

Felfili, J.M. 1995. Diversity, structure and dynamics of a gallery forest in central Brazil. Vegetatio, 117: 1-15.

Felfili, J.M. 1997. Diameter and height distributions in a gallery forest tree community and some of its main species in central Brazil over a six-year period (1985-1991). Revista Brasileira de Botânica, 20: 155-162.

Felfili, J.M. 2000. Crescimento, recrutamento e mortalidade nas matas de galeria do Planalto Central, p. 152-158. In: Cavalcanti, T.B.; Walter, B.M.T. (Orgs). Tópicos Atuais em Botânica, SBB/ Embrapa-Cenargen, Brasília, Brasil.

Felfili, J.M.; Abreu, H.A.M. 1999. Regeneraçâo natural de Roupala montana Aubl., Piptocapha macropoda Back. e Persea fusca Mez. em quatro condiçóes ambientais em mata de galeria na mata de galeria do Gama-D.F. Revista Cerne, 6: 125-132.

Felfili, J.M.; Ribeiro, J.F.; Fagg, C.W.; Machado, J.W.B. 2000. Recuperação de Matas de Galeria. Embrapa-Cerrados, Planaltina, Brasil.
Felfili, J.M.; Silva-Júnior, M.C. 1992. Floristic composition, phytosociology and comparison of cerrado and gallery forests at Fazenda Água Limpa, Federal District, Brazil, p. 393-415. In: Furley, P.A.; Proctor, J.A.; Ratter, J.A. (Eds). Nature and dynamics offorest-savanna boundaries, Chapman \& Hall, London, England.

Furley, P.A.; Ratter, J.A. 1988. Soil resources and plant communities of the central Brazilian cerrado and their development. Journal of Biogeography, 15: 97-108.

Haridasan, M.; Araújo, G.M. 1988. Aluminium accumulating species in two forest communities in the cerrado region of the central Brazil. Forest Ecology and Management, 24: 15-26.

Hornung, M. 1990. Measurement of nutrient losses resulting from soil erosion, p. 80-102. In: Harrison, A.F.; Ineson, P.; Heal, O.W. (Eds). Nutrient cycling in terrestrial ecosystems. Elsevier Applied Sciences, London.

Hubbell, S.P. 1979. Tree dispersion, abundance, and diversity in a tropical dry forest. Science, 203: 1299-1309.

Hubbel, S.P.; Foster, R.B. 1987. La estructura espacial en gran escala de un bosque neotropical. Revista de Biologia Tropical, 35: 7-22.

Ivanauskas, N. M.; Monteiro, R.; Rodrigues, R.R. 2003. Relaçôes florísticas entre florestas deciduais, semideciduais e perenifólias na região Centro-Oeste do Brasil, p.313-322. In: Claudino-Sales, V. (Org). Ecossistemas Brasileiros: Manejo e Conservação. Expressão Gráfica e Editora, Fortaleza, Brasil.

Kellman, M.; Tackberry, R.; Brokaw, N.; Meave, J. 1994. Tropical gallery forests. National Geographic Research \& Exploration, 10: 92-103.

Las Salas, G. 1987. Suelos y ecosistemas forestales; con énfasis en América Tropical. Instituto Interamericano de Cooperación para la Agricultura, San José, Costa Rica.

Lieberman, D. 1996. Demography of tropical tree seedlings: a review, p. 131-138. In: Swaine, M.D. (Ed). The ecology of tropical tree seedlings. UNESCO/Parthenon, Paris.

Marimon, B.S.; Felfili, J.M.; Lima, E.S. 2002. Floristics and phytosociology of the gallery forest of the Bacaba Stream, Nova Xavantina, Mato Grosso, Brazil. Edinburgh Journal of Botany, 59: 303-318.

Marimon, B.S.; Felfili, J.M.; Lima, E.S.; Rodrigues, A.J. 2001. Distribuições de circunferências e alturas em três porçôes da mata de galeria do Córrego Bacaba, Nova Xavantina-MT. Revista Árvore, 25: 335-343.

Marimon, B.S.; Varella, R.F.; Marimon-Júnior, B.H. 1998. Fitossociologia de uma área de cerrado de encosta em Nova Xavantina, Mato Grosso. Boletim do Herbário Ezechias Paulo Heringer, 3: 82-101.

Marimon-Júnior, B.H.; Haridasan, M. 2005. Comparação da vegetação arbórea e características edáficas de um cerradão e um cerrado sensu stricto em áreas adjacentes sobre solo distrófico no leste de Mato Grosso, Brasil. Acta Botanica Brasilica, 19: 915-928. 
Meave, J.; Kellman, M.; Mac Dougall, A.; Rosales, J. 1991. Riparian habitats as tropical forest refugia. Global Ecology and Biogeography Letters, 1: 69-76.

Medina, E. 1995. Diversity of life-forms of high plants in neotropical dry forests. In: Bullock, S.H.; Mooney, H.A.; Medina, E. (Eds). Seasonally dry tropical forests. Cambridge University Press, Cambridge. p. 221-242.

Miguel, A.; Marimon, B.S. Mudanças na composição florística e na diversidade de espécies em três áreas da mata de galeria do Córrego Bacaba (Nova Xavantina, MT), p. 93-116. In: Santos, J.E.; Galbiati, C. (Orgs). Gestão e Educação Ambiental: Água, Biodiversidade e Cultura. Ed. Rima, São Carlos, Vol. 1.

Mueller-Dombois, D.; Ellenberg, H. 1974. Aims and methods of vegetation ecology. J. Wiley \& Sons, New York, USA.

Nascimento, M.T.; Hay, J.D. 1990. Taxa de herbivoria foliar em jovens de Metrodorea pubescens St. Hil. and Tull. (Rutaceae) da mata do Ribeirão do Gama-DF, p. 229-309 In: Barbosa, L.M. (Ed). Anais do Simpósio sobre Mata Ciliar. Fundação Cargill, Campinas, Brasil.

Oliveira-Filho, A.T.; Vilela, E.A.; Carvalho, D.A.; Gavilanes, M.L. 1994b. Effects of soils and topography on the distribution of tree species in a tropical riverine forest in south-eastern Brazil. Journal of Tropical Ecology, 10: 483-508.

Oliveira-Filho, A.T.; Vilela, E.A.; Gavilanes, M.L.; Carvalho, D.A. 1994c. Effect of flooding regime and understorey bamboos in the physiognomy and tree species composition of a tropical semideciduous forest in Southeastern Brazil. Vegetatio, 113: 99-124.

Oliveira-Filho, A.T.; Martins, F.R. 1986. Distribuição, caracterização e composição florística das formaçôes vegetais da região da Salgadeira, na Chapada dos Guimarães (MT). Revista Brasileira de Botânica, 9: 207-223.

Oliveira-Filho, A.T.; Ratter, J.A. 1995. A study of the origin of central Brazilian forests by the analysis of plant species distribution patterns. Edinburgh Journal of Botany, 52: 141-194.

Oliveira-Filho, A.T.; Ratter, J.A.; Shepherd, G.J. 1990. Floristic composition and community structure of a central Brazilian gallery forest. Flora, 184: 103-117.

Oliveira-Filho, A.T.; Scolforo, J.R.S.; Mello, J.M. 1994a. Composição florística e estrutura comunitária de um remanescente de floresta semidecídua montana em Lavras, MG. Revista Brasileira de Botânica, 17: 167-182.

Oliveira-Filho, A.T.; Curi, N., Vilela, E.A.; Carvalho, D.A. 1998. Effects of canopy gaps, topography and soils on the distribution of woody species in a central Brazilian deciduous dry forest. Biotropica, 30: 362-375.

Oliveira, E.C.L.; Felfili, J.M. 2005. Estrutura e dinâmica da regeneraçáo natural de uma mata de galeria no Distrito Federal, Brasil. Acta Botanica Brasilica, 19: 803-813

Paula-Lima, W.; Zakia, M.J.B. 2000. Hidrologia de Matas Ciliares, p. 33-44. In: Rodrigues, R. R.; Leitão-Filho, H.F. (Eds). Matas Ciliares: conservação e recuperação. EDUSP/FAPESP, São Paulo, Brasil.
Philip, M.S. 1994. Measuring trees and forests. University Press, Cambridge.

Pinto, J.R.R.; Oliveira-Filho, A.T. 1999. Perfil florístico e estrutura da comunidade arbórea de uma floresta de vale no Parque Nacional da Chapada dos Guimarães, Mato Grosso, Brasil. Revista Brasileira de Botânica, 22: 53-67.

Pires, J.M.; Prance, G.T. 1977. The Amazon Forest: a natural heritage to be preserved, p. 158-194. In: Prance, G.T.; Elias, E.S. (Eds). Extinction is forever - Threatened and endangered species of plants in the Americas and their significance in ecosystems today and in the future. Proceedings of a Symposium held at the New York Botanical Garden. New York, USA.

Prado, D.E.; Gibbs, P.E. 1993. Patterns of species distributions in the dry seasonal forests of South America. Annals of the Missouri Botanical Garden, 80: 902-927.

Ratter, J. A.; Ribeiro, J.F.; Bridgewater, S. 1997. The Brazilian Cerrado vegetation and threats to its biodiversity. Annals of Botany, 80: 223-230.

Ratter, J.A.; Richards, P.W.; Argent, G.; Gifford, D.R. 1973. Observations on the vegetation of the northeastern Mato Grosso. I. The woody vegetation types of the Xavantina-Cachimbo expedition area. Philosophical Transactions of the Royal Society of London Biological Sciences, 226: 449-492.

Rodewald, A.D.; Bakermans, M.H. 2006. What is the appropriate paradigm for riparian forest conservation? Biological Conservation, 128: $193-200$.

Sampaio, A.B.; Walter, B.M.T.; Felfili, J.M. 2000. Diversidade e distribuição de espécies arbóreas em duas matas de galeria na micro-bacia do Riacho Fundo, Distrito Federal. Acta Botanica Brasilica, 14: 197-214.

SAS. 1999-2000. SAS User's Guide. SAS Institute, Carey, NC, USA.

Sevilha, A.C. 1999. Composição e estrutura da mata de galeria do Capetinga, na Fazenda Água Limpa, Brasilia, DF, dez anos após um incêndio acidental. Master Thesis. Universidade de Brasília, Brasília, Brazil.

Silva-Júnior, M.C.; Felfili, J.M.; Walter, B.MT.; Nogueira, P.E.; Rezende, A.V.; Morais, R.O.; Nóbrega, G.G. 2001. Análise da flora arbórea de matas de galeria no Distrito Federal: 21 levantamentos, p. 143-191. In: Ribeiro, J.F.; Fonseca, C.E.L.; Sousa-Silva, J.C. (Eds). Cerrado: caracterização e recuperação de matas de galeria. Embrapa-Cerrados, Planaltina, Brazil.

Silva-Júnior, M.C.; Furley, P.A.; Ratter, J.A. 1996. Variation in the tree communities and soils with slope in gallery forest, Federal District, Brazil, p. 451-469. In: Anderson, M.G.; Brooks, S.M. (Eds). Advances in hillslope processes. John Wiley \& Sons, London, England. Silva, J.F.; Farinas, M.R.; Felfili, J.M.; Klink, C. 2006. A Spatial heterogeneity, land use and conservation in the cerrado region of Brazil. Journal of Biogeography, 33: 536-548.

Smilauer, P. 1992. CANODRAW: User's guide (v. 3.0). Microcomputer Power, Ithaca, New York, USA. 
Swaine, M.D. 1989. Population dynamics of tree species in tropical forests, p. 101-110. In: Holm-Nielsen, L.B., Nielsen, I.C.; Balslev, H. (Eds). Tropical Forests; botanical dynamics, speciation and diversity. Academic Press, London, England.

Swaine, M.D.; Whitmore, T.C. 1988. On the definition of ecological species groups in tropical rain forests. Vegetatio, 75: 81-86.

Tabachnick, B.G.; Fidell, L.S. 2001. Using Multivariate Statistics. Harper Collins Pub. Inc., New York, USA.

Tan, K.H. 1996. Soil sampling, preparation, and analysis. Marcel Dekker Inc., New York, USA.

Ter Braak, C.J.; Smilauer, P. 1998. CANOCO-Reference Manual and User's guide to Canoco for Windows: software for Canonical Community Ordination (version 4). Microcomputer Power, Ithaca, New York, USA.
Whitmore, T.C. 1984. Tropical rain forests of the Far East. Oxford University Press, Oxford, England.

Whitmore, T.C. 1990. An introduction to tropical rainforests. Claredon Press, Oxford, England.

Recebido em: 19/04/2009

Aceito em: 25/05/2009 